\title{
ガラスの分相抽び結晶化の過程についで
}

\author{
守屋喜 郎**
}

\section{Phase Separation and Crystallization Process in Glasses}

by

\author{
Yoshiro MORIYA
}

(Government Industrial Research Institute, Osaka)

\section{1 はしがき}

ガラスの構造は従来考兄られていた活ど均質なもの ではなく，微視的にみればかなり不均質であり，先の 不均質性のため代ガラスの強度, 化学的耐久性, 電気 的性質あるいはカラス中に導入された微量成分の挙動 などが影響を受沙ることが最近徐々に明らかにされつ つある.そして, この微細な不均質相発生の重要な原 因の一つとして分相 (単一相のガラスが二つ以上のガ ラス相に分れる現象）が考えられている。 そのため, 分相現象を明らかにすることはガラスの構造や物性を 理解するための有力な手段となる。そればかりでなく, 分相は“バイコール”ガラスの製造に和ける必須過程 である活か, ガラスの結晶化漈しても, 結晶核生成 速度や析出結晶の大きさ，種類などに影響を与える可を 能性があるので，新しいがラスを製造する立場からも， 分相に関する知識はきわめて重要である。本稿では," まずガラスの分相現象について述べ，ついでガラスの 結晶化の初期過程, とくに分相と結晶化との関係につ いて概説する。

\section{2 成分系における不混和}

簡単のために, $x A(100-x) B$ の組成の 2 成分溶液 を考光る。系の自由エネルギ $F$ は，内部ェネルギを $U$, エントロピーを $S$, 温度を $T\left({ }^{\circ} \mathrm{K}\right)$ とすれば, $F$ $=U-S T$ で表わされる，Uも $S$ も組成 $C$ の関数であ る. い要温度 $T=T_{0}$ に打いて $F-C$ 曲線が $A$ から $B$ にかけて Fig. 1 (a) 汇示すように変化するならば， $x A$ $(100-x) B$ 組成の溶液は単一相として安定に存在する. しかし温度が低下して，T=T1 に打ける $F-C$ 曲線が

* 原稿受理 昭和 45 年 7 月 6 日

** 大阪工業技術試験所 他田市緑ヶ丘

*1 $\mathrm{SiO}_{2} 70, \mathrm{~B}_{2} \mathrm{O}_{3} 22.5, \mathrm{Na}_{2} \mathrm{O} 7.5$ (wt \%) 付近の比較的軟質の矹珪酸 ガラスを溶融成型後, 熱処理一酸処理一乾燥一焼成によって作ら れる石英ガラス類似の高珪酸ガラス.その組成はほほ $\mathrm{S}_{2} \mathrm{O}_{2} 96.3$, $\mathrm{B}_{2} \mathrm{O}_{3} 29, \mathrm{Al}_{2} \mathrm{O}_{3} 0.4, \mathrm{Na}_{2} \mathrm{O} 002$ (wt \%) 亿相当する1).
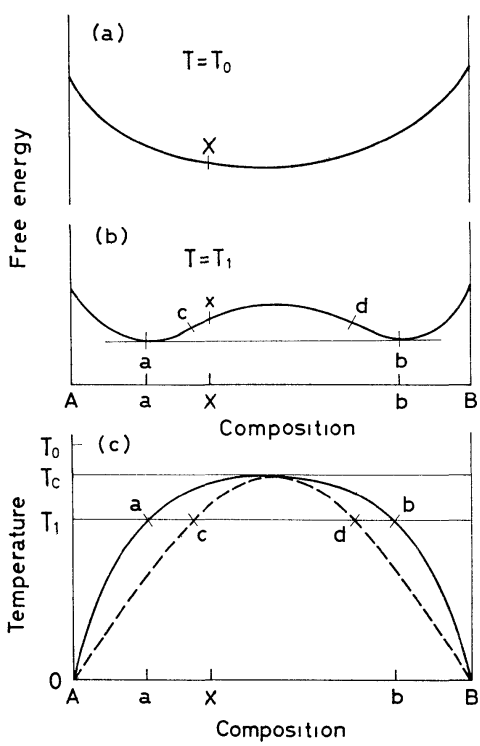

Fig. 1. Free energy-composition diagrams and phase diagram for a simple binary system which develops immiscibility on cooling.

Fig. 1(b)のようになると, 二つの極小点 $\mathrm{a}, \mathrm{b}$ 間の組 成では, 単一相の自由エネルギは $a$ 㐨上び $b$ の組成よ りなる 2 相の混合物のそれより高くなり，したがって 溶液は 2 相に分かれた方が安定となる。一般に温度が 低下するほど極小点 $\mathrm{a}, \mathrm{b}$ は末端組成 $A, B$ V近ずく ので， $A, B 2$ 成分系の相平衡図はFig. 1(c)のように なる。ここで実線は不混和の境界線を表わし，破線は $F-C$ 曲線の変曲点 (Fig. 1 (b) 飞扔いては C と d) の 軌跡でスピノーダルと呼ばれている。また $T_{c}$ は上部 臨界温度である。

2 成分酸化物系で認められる不混和の形も上で述べ たのと基本的には同じである。しかし，相平衡㘠は結 晶相の出現のためにより複雑になる。 Fig. 2 は不混和 を示す酸化物系の典型的な相平衡図とそれに対応する 
$F-C$ 曲線を模式的に表わしたものであり，また Fig. 3 は，その一例として， $\mathrm{CaO}-\mathrm{SiO}_{2}$ 系の液相温度付近の 相平衡図の一部を示したものである。

Fig. 3 から容易に推測されるように, $\mathrm{CaO}-\mathrm{SiO}_{2}$ 系

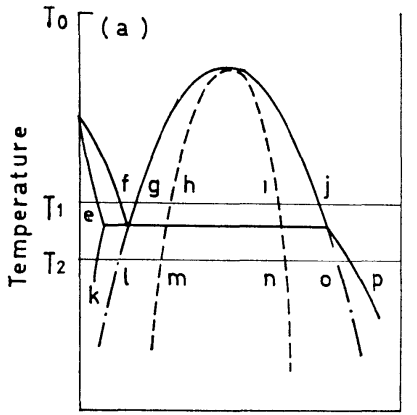

Composition

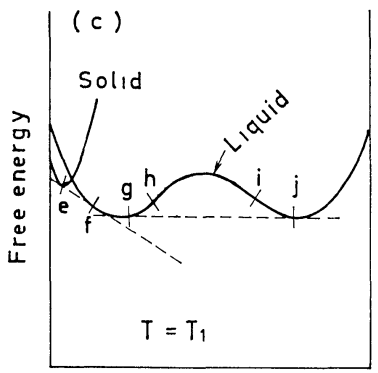

Composition

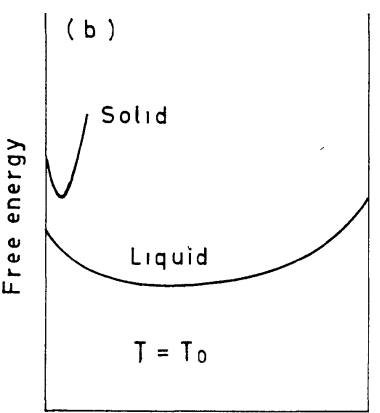

Composition

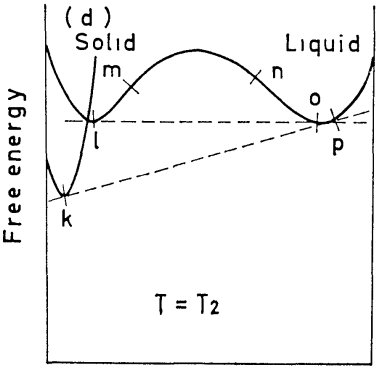

Composition
F1g. 2. (a) Schematic phase diagram showing the phase boundary and spinodal of a two-liquid immiscibility region and the solid solubility behavior of an unrelated third crystalline phase. (b), (c) and (d) Free energy. composition diagram for the temperatures given in (a). Horizontal tangents on the liquid curves determine the coexisting liquid compositions. Tangents touching both liquid and solid curves determine liquidus and solidus compositions (See reference 2).

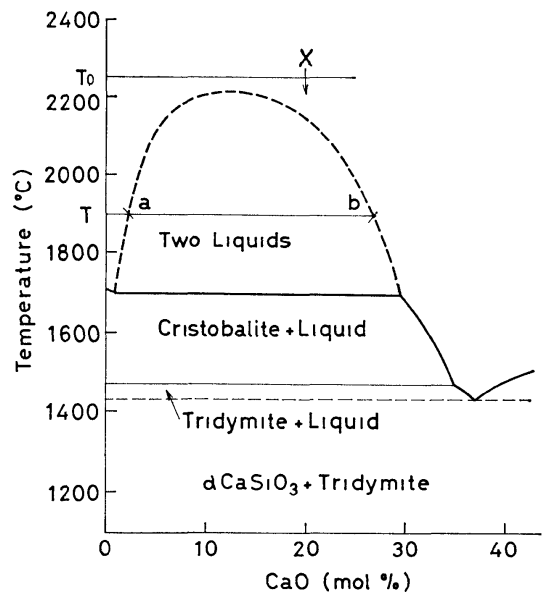

Fig. 3. Phase diagram for $\mathrm{CaO}-\mathrm{SiO}_{2}$ system. Tc was quoted from reference 4 .
では温度 $T_{0}$ で均質であった $x$ の組成（たとえば $\mathrm{SiO}_{2}$ $80, \mathrm{CaO} 20(\mathrm{~mol} \%))$ の融液は, 温度 $T$ まで冷却さ る れると $a ， b$ 組成の 2 相に分かれる。 そして温度の低 下とともに，各相の組成は破線に沿って变化し， $1700^{\circ} \mathrm{C}$ 付近でクリストバライトを析出す る.この組成では, 不混和を起こす温度域 での粘性が低いので， $T_{0}$ より急冷しても 均質なガラスをうることはできない。

F-C 曲線が Fig. 4 のように変化すると きは，2相分離は液相温度以下で起こる。 このような相平衡図淮相当するガラス生成 系では, 多くの場合不混和の起こる温度域

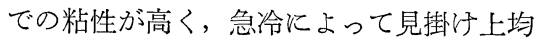
質なガラスが得られるので，この型の不混 和はしばしば準安定な不混和と呼ばれる。 その典型が $\mathrm{Li}_{2} \mathrm{O}-\mathrm{SiO}_{2}$ あるいは $\mathrm{Na}_{2} \mathrm{O}-\mathrm{SiO}_{2}$ 系である. $\mathrm{Li}_{2} \mathrm{O}-\mathrm{SiO}_{2}$ 系の相平衡㘠を Fig. 5 亿示す.

この $\mathrm{Li}_{2}{\mathrm{O}-\mathrm{SiO}_{2}}_{2}$ 系では, $\mathrm{SiO}_{2} 72 \sim 69$, $\mathrm{LiO}_{2}$ 28〜31 (mol \%) の組成の融液は, たと光冷却中に不混和領域に突入するとし ても，急冷によって単一相のガラスにな る.もちろんそのガラスは潜在的な不混和 傾向を有しているので, 転移点以上の適当 な温度で再加熱すると 2 相分離する.この ように, 準安定な不混和性を有する組成 は, 冷却条件によっては均質なガラスも得 られ，また熱処理条件によってある程度分 相構造を制御することもできるので，分相 を速度論的に研究する場合, あるいは分相 を利用してガラスに新しい性質を付与しよ うとする場合に興味深いものである。

\section{3 分相構造の二つのタイプ}

一般に分相したガラスは, 光の散乱のために, 外観 上青白く濁ってみえる。そのよらなガラスの薄膜ある いは希フッ化水素酸で軽く腐食した破断面のレプリカ を電子顕微鏡で観察してみると，2相の存在が明りよ ら汇認められる. Fig. 6 は典型的な分相構造を示す電 子顕微鏡写真で, $\mathrm{SiO}_{2} 75, \mathrm{Li}_{2} \mathrm{O} 25$ 特よび $\mathrm{SiO}_{2} 90, \mathrm{Na}_{2}$ $\mathrm{O} 10(\mathrm{~mol} \%)$ 組成のガラスからとられたものである. ここで盛り上ってみ元る部分はいずれも $\mathrm{SiO}_{2}$ 約 $100 \%$, 他の部分は元の組成よりアルカリに富んだ組成のガラ スに対応している。

2 枚の写真を比較してみると明らかなように，Fig. 6 (a)では球形粒子が個々独立して存在しているのに対 し, Fig. 6 (b)では分離した 2 相が互いに複雑にからみ 合っている。このうち，2相のからみ合った構造は “バイコール”ガラスを製造する際の必須の分相構造で 


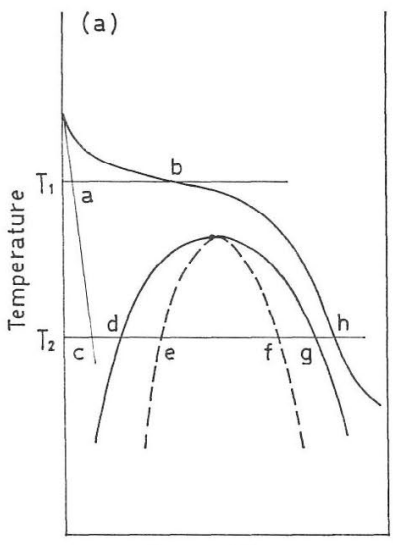

Composition

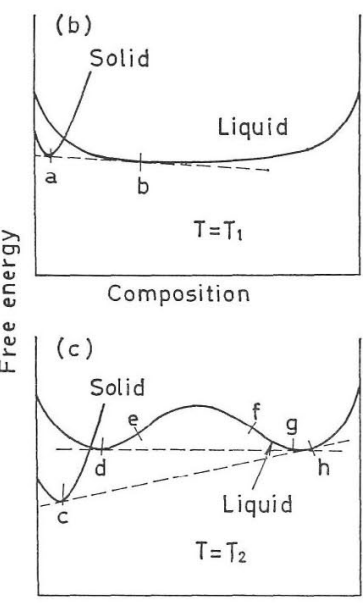

Composition

Fig. 4. (a) Schematic phase diagram showing a sub-liquidus immiscibility region and an unrelated crystalline phase. (b) and (c) Free energy-composition diagrams corresponding to temperatures given in (a) (See reference 2).

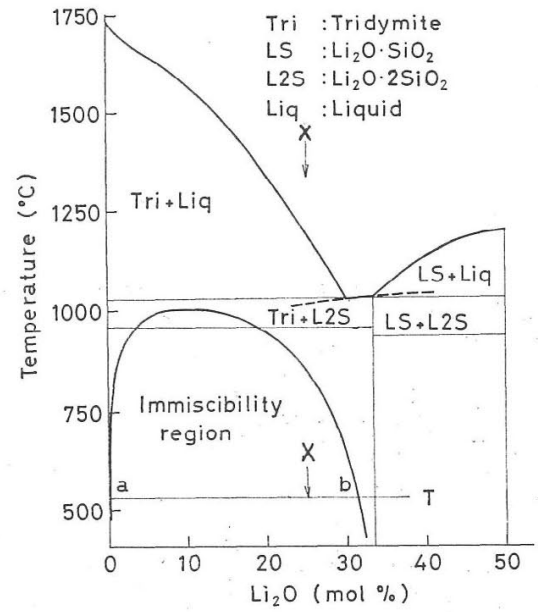

Fig. 5. Phase diagram for $\mathrm{Li}_{2} \mathrm{O}-\mathrm{SiO}_{2}$ system.

ある棌か，結晶化ガラスの製造のための結晶核生成の 前段階としてる望ましい構造であると考えられている。 このような独立した球形粒子とからみ合いといら二つ の特徴的な構造の違いは, 主としてて分相前のガラスの 組成の湋いによるものであるが，そればかりでなく， 分離相の生成ならびに成長機構の違いによっても生ず るもので㐫る。

\section{$3 \cdot 1$ 独立した球形粒子の場合}

分相粒子が個及独立した球形粒子として存在する分 相構造は，一般に分相核の生成ついでその成長という 機構（核生成一成長機構）飞従って分相が進行する場 合に得占れやすい。この場合，分相核の生成には古典 的な核生成理論が適用され，关の速度 $I_{0}$ は(1)式で表 わされる。

$$
I_{c}=\text { const } \cdot \exp \left[-\frac{1}{k T}\{\Delta G+W *\}\right]
$$

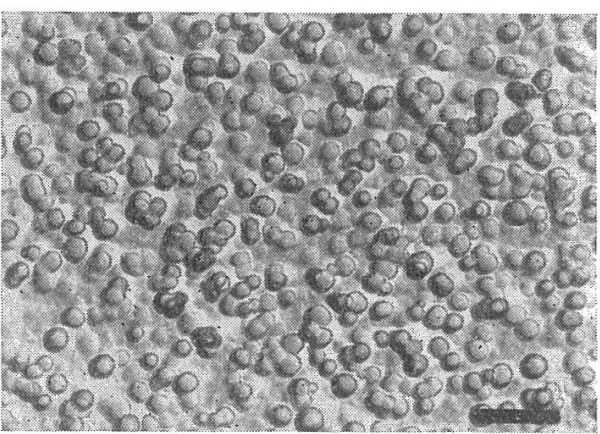

(a)

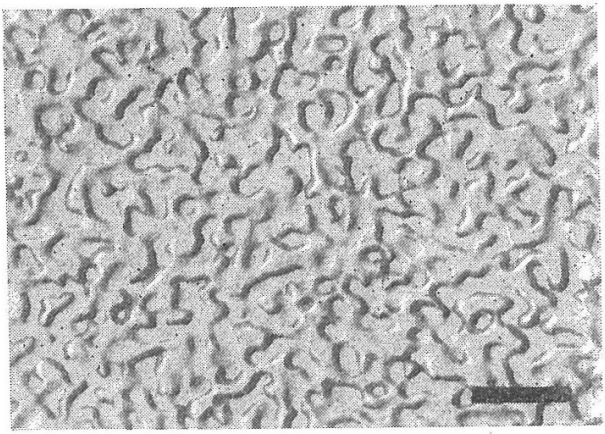

(b)

Fig. 6. Electron micrographs of fracturc surfaces of (a) $\mathrm{SiO}_{2} 75, \mathrm{Li}_{2} \mathrm{O} 25$ (mol \%) glass as cast and (b) $\mathrm{SiO}_{2} 90, \mathrm{Na}_{2} \mathrm{O} 10$ (mol \%) glass heat treated at $771^{\circ} \mathrm{C}$ for $10 \mathrm{~min}$. Black bars represent 0.3 micron.

$$
\text { const } \cdot \exp \left[-\frac{1}{k T}\left\{\Delta G+\frac{16 \pi \sigma^{3}}{3 \Delta S_{v}{ }^{2}\left(\Delta T_{m}\right)^{2}}\right\}\right]
$$

ここで $\Delta G$ は拡散の活性化ェネルギ，W* は核生成 のための熱力学的障壁, のは核之母液間の界面張力, $\Delta S_{v}$ は単位体積当たりのエントロピー変化, $\Delta T_{m}(=$ $\left.T_{m}-T\right)$ は混和温度 $T_{m}$ からの過冷却度, $k$ はボルッ マン定数，Tは絶刘温度で㐫る。

この式から明らかなように，温度が一定の場合には， 一般に混和温度が低く, 粘性係数の大きい組成活ぞ $I_{c}$ は小となる。そして比較的狭い温度範囲では， $I_{c}$ の対 数と $1 / T \Delta T_{m}{ }^{2}$ との関係は直線となる。

分散した球形粒子の成長速度は, 結晶成長速度の場 合之同様飞, $T_{m}$ (結晶の場合は液相温度) が低々, 粘 性係数の大きい組成漹ど小さい，そして，分離相の体 積分率が一定值に達するまでは, 粒子径は加熱保持時 間の $1 / 2$ 乗に比例して増加する。しかし体積分率が一定 值に達した後では，小さい粒子が溶けて大きな粒子が 成長するといら機構で成長するために，粒子径は加熱 時間の $1 / 3$ 乗に比例して増加する。

\section{$3 \cdot 2$ 少らみ合い構造の場合}

一力Fig. 6 (b)火示したようなから文合い構造の発生 
には、三つの機構が考克られている。一つはスピノー ダル分解による場合であり，他は(1)式によっていった え生成した球形粒子が互いに融合，再配列して 2 相が ふふらら合った状態になる場合である。

前述のよ5に, Fig. 1 (b)の a, b間の緍成 $x$ の溶液 (この場合はガラス）は温度 $T_{1}$ では，組成が $a ， b$ て，その体積分率が $f_{v a} / f_{v b}=d_{b} / d_{a} \cdot \overline{\mathrm{xb}} / \overline{\mathrm{xa}}$ で表わさ 机る 2 相に分加当。ただし $f_{v a}, f_{v b}$ は $a, b$ 冬相の 体積分率， $d_{a}, d_{b}$ は久の密度である。乙かし初めか ら上の状態に達するのではなくて, 最初は小さな組成 変動から出発するであろう。そのような組成変動が采 の自由エネルギに及ぼす效果は, 組成 $a, b$ を通じて 必方ずしも同じとは限らない。cd 問では $d^{2} F / d C^{2}<0$, 一方 $\mathrm{ac}$ 就よび bd 間では $d^{2} F / d C^{2}>0$ から推測され るように，cd 間では小さい組成変動は自由エネルギ の減少に導き, 一方 $\mathrm{ac}$ 和よび bd 間では逆に増加に 導く。乙たがって，cd 間では単一相は小さい組成・ 変動に対して不安定であり, 最初生じた変動涊さらに
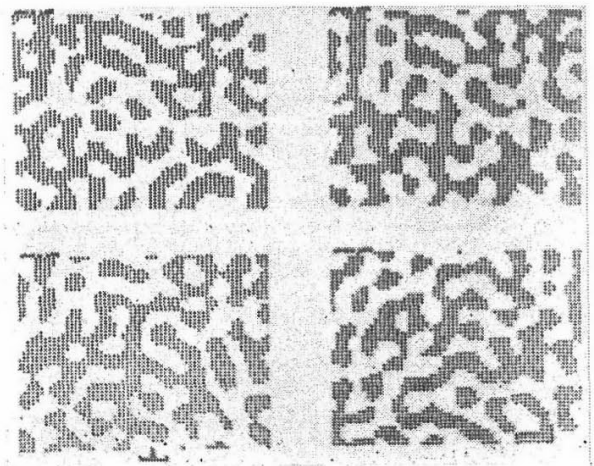

(a)

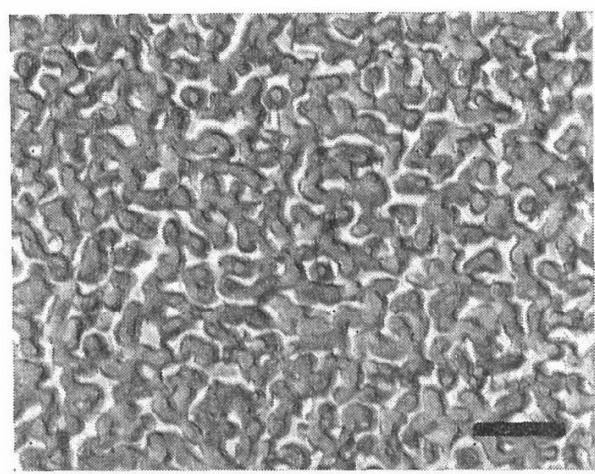

(b)

Fig. 7. (a) A succession of computed sections through a two phase structure (Each phase occupies 50 vol $\%$ ) for 100 random sine waves showing the degree of connectivity and the relationship between the distribution of phases and characteristic wave length, $\lambda$ (Seo reference 9). (b) Electron micrograph of fracture surface of phase separated borosilicate glass. Black bar represents 0.2 micron.
一勫助長されることになる。すなわら拡散抵抗が大き くないかぎり, 分相は自然に起こる(スピ)ーダル分 解による分相).

これに齐して，ac拈よび bd 間では小さな組成変動 に詨しては単一相は安定でありたと党とのよらな組 成変動が起こったとしても自然に消失してしまら。市 る大ささ以上の変動のみが 2 相分離に導く. 分相核の 生成に(1)式が適用されるのはこの領域内で起こる分相 についてである。

スピノーダル領域で起こる分相過程については, Cahn が詳細に解析し, 組成変動が波長 $2 \pi / \beta$ の正弦 波，才なわ方 $A \cos \beta x$ ( $x$ は距離を表わす) の形，の 組及合せで表わされる場合には，一定值 $\beta_{c}$ 上り小さ い波数をもつ変動のみが安定で分相に貢献することを 示した。そして組成変動学, 波長は一定であるが方位 も位相も振幅も不規則な正弦波の重畳によるとして計 算した分相構造 (奏際は断面の構造) は, Fig. 7 (a) に 示すように，2相が複雑に入り組んだ形になり，“バ イコール”ガラスの元になる嗍珪酸ガラスの分相構造 (Fig.7 (b)) に非常によく似ていることを示した。 この ことが，2相のからみ合った分相構造はスピノーダル 分解によって生ずる，という考光方の一つの根扰とな っている。

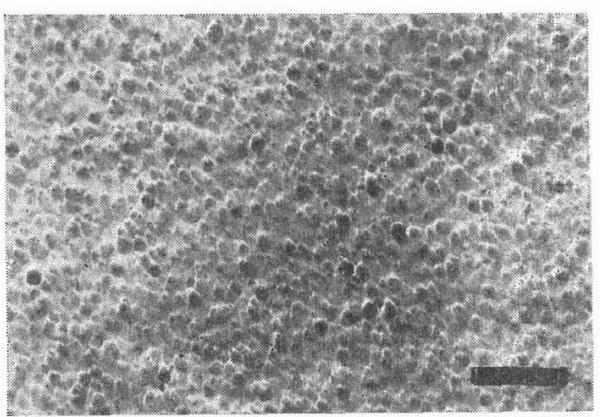

(a)

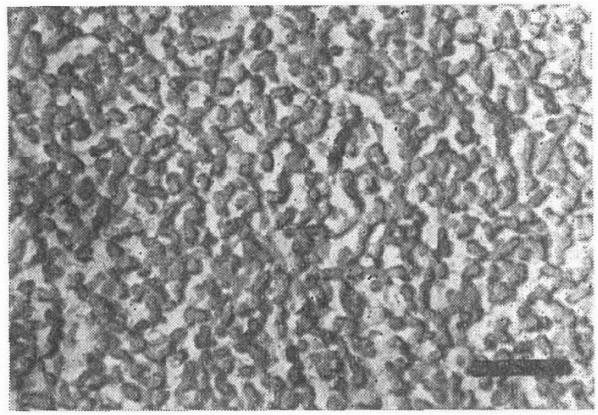

(b)

Fig. 8. Electron micrographs of fracture surfaces of $\mathrm{SiO}_{2} 75, \mathrm{Li}_{2} \mathrm{O} 25$ (mol \%6) glasses with different thermal histories. Black bars represent 0.3 micron. (a) Quenched in cold water. (b) Quenched in cold water and then heat treated at $488^{\circ} \mathrm{C}$ for $72 \mathrm{hr}$. 


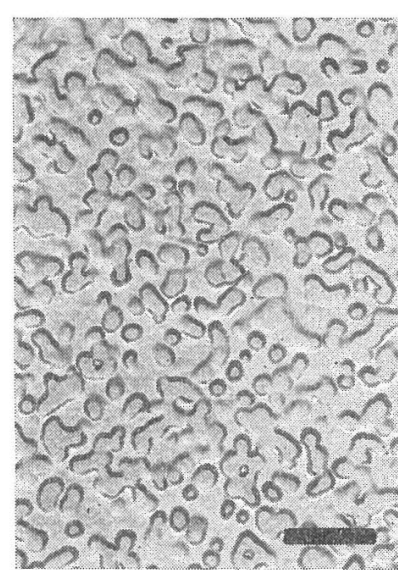

(a)

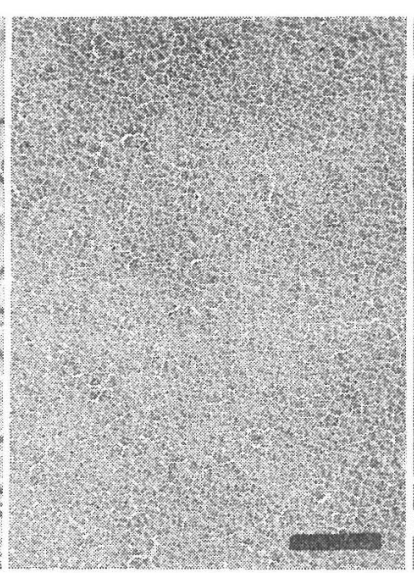

(b)

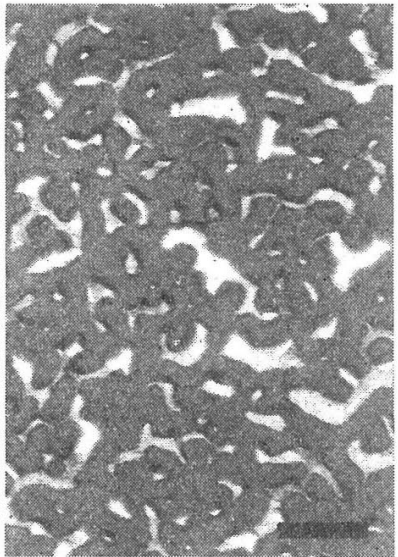

(c)

Fig. 9. Electron micrographs of fracture surfaces of $\mathrm{SiO}_{2} 85$, $\mathrm{Na}_{2} \mathrm{O} 15+\mathrm{B}_{2} \mathrm{O}_{3} x$ (wt $\%$ ) glasses heat treated at $600^{\circ} \mathrm{C}$ for $72 \mathrm{hr}$. Black bars represent 0.3 micron.

$\begin{array}{lll}\text { (a) } x=0 & \text { (b) } x=15 & \text { (c) } x=30\end{array}$

しかし，2相のからみ合った構造の発生だけについ てい光ば, 必らずしも气れをスピノーダル分解でけに 限定する必要はない。多数の粒子が互いに接触して存 在するときには，界面積を減少させる力が駆動力とな って, 溶解度の大きい曲率半径の小さい部分が溶解し, 曲率半径の大きい所に析出する過程をたどって非球形 に成長し， 2 相のからみ合った構造へと発展ずること も可能であうう. Fig. 8 亿はこの考光を支持すると思 われる写真を示す。ここでFig. 8 (b)はFig. 8 (a)の構造 を示すがラスを低温で再加熱した試料からとられたる ので, 初めの粒状構造がからみ合い構造に変化してい るのがわかるであるう。

スピノーダル分解によって分相が進行する場合には, 分相の時定数て (分相の早さの目安, てが小さいほど 分相速度が大）は(2)式で表わされる。

$$
\tau=\frac{\lambda^{2}}{8 \pi^{2} D} \cdot \frac{T}{\Delta T_{s}}
$$

ここでんは modulated structure の波長, D は拡 散係数, $\Delta T_{s}\left(=T_{s}-T\right)$ はスピノーダル温度 $T_{s}$ から の過冷却度である。温度の低下とともに $\Delta T_{s}$ の增加 によってては小さくなるが, 同時にDの減少によって ての減少は押光られ, 結果と乙てて最小, 換言すれば スピノーダル分解速度最大の温度が存在する。計算に よると， $\Delta T_{s} / T \cong 0.1$ のときて $て$ は最小となり, スピ， 一ダル分解が最も早く起こる。. Fig. 6 (b) と示した $\mathrm{SiO}_{2}$ 90, $\mathrm{Na}_{2} \mathrm{O} 10(\mathrm{~mol} \%)$ 組成のガラスでは, $T_{s} \sim 1090$ 。 $\mathrm{K}$ (から又合い構造が得られる最高温度から推翨),

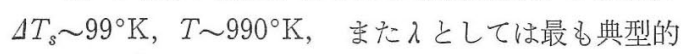
な值 $100 \AA$ を仮定すると，

$$
\begin{aligned}
\bar{\sigma}_{\min } & \sim \frac{10^{4} \times 10^{-16} \times 990}{8 \times 3.14^{2} \times D \times 99}=1.27 \times \frac{10^{-13}}{D} \\
& \sim \frac{10^{-13}}{D} \quad(\mathrm{sec})
\end{aligned}
$$

となる。分相粒子の成長の活性化ェネルギ５0 80 $\mathrm{kcal} / \mathrm{moI}_{13}^{12}$ は酸素イオンの拡散の活性化エネルギ 60 $70 \mathrm{kcal} / \mathrm{mol}$ に近いことから，Dの値として酸素イオ ンの拡散係数として期待される值 $D \sim 10^{-13} \sim 10^{-16}$ $\left(\mathrm{cm}^{2} / \mathrm{sec}\right)^{13}$ をとれば, $\tau_{\min } \sim 1 \sim 1000 \mathrm{sec}$ となる。す なわち $\mathrm{SiO}_{2} 90, \mathrm{Na}_{2} \mathrm{O} 10(\mathrm{~mol} \%)$ 組成では, 融液 を突然 $718^{\circ} \mathrm{C}$ に冷却したとしても，その温度で上記の 時間以上に保持するとスピノーダル分解に上る分相が 起こることになる。

\section{4 アルカリ珪酸塩ガラスの分相に及ぼす第 3 成分 の影響}

アルカリーシリカ 2 成分系のうち、 $\mathrm{Li}_{2} \mathrm{O}-\mathrm{SiO}_{2}$ 系で は $\mathrm{Li}_{2} \mathrm{O}$ 約31 (mol\%) 以下, $\mathrm{Na}_{2} \mathrm{O}-\mathrm{SiO}_{2}$ 系では $\mathrm{Na}_{2} \mathrm{O}$ 約20 (mol\%) 以下の組成のガラスで分相することが 確認されているが， $\mathrm{K}_{2} \mathrm{O}-\mathrm{SiO}_{2}, \quad \mathrm{Rb}_{2} \mathrm{O}-\mathrm{SiO}_{2}$ 㧊よび $\mathrm{Cs}_{2} \mathrm{O}-\mathrm{SiO}_{2}$ 系では, いなど分相は観察されていない。

ところで $\mathrm{Li}_{2} \mathrm{O}-\mathrm{SiO}_{2}$ あるいは $\mathrm{Na}_{2} \mathrm{O}-\mathrm{SiO}_{2}$ 系の組成 第 3 成分を添加すると, 前節で述べたことから容易 に推測される上らに, 混和温度を上げる成分は分相を 助長し, 粘性を高める成分は逆に分相を抑制するよう に作用する。このことは電子顕微鏡による観察結果に よっても裏づけら机ている。つぎにいくつかの成分の 添加の影響を示す。

\section{$4 \cdot 1$ アルカリ金属酸化物}

$\mathrm{Li}_{2} \mathrm{O}<\mathrm{Na}_{2} \mathrm{O}<\mathrm{K}_{2} \mathrm{O}<\mathrm{Rb}_{2} \mathrm{O}<\mathrm{CS}_{2} \mathrm{O}$ の順に, 分相を抑 制する効果が大となる。

\section{$4 \cdot 2$ アルカリ金属酸化物以外の成分}

*2 ここでいう分相は $\mathrm{SiO}_{2}$ に富む組成城で起こる分相で, その分離 相の一つの組成は $\mathrm{SiO}_{2} 100 \%$ 亿近い. 個々の成分の勏果の詳紐は 文献14）および15) 参照.

*3 $\mathrm{K}_{2} \mathrm{O}-\mathrm{SiO}_{2}$ 系では, $\mathrm{K}_{2} \mathrm{O}$ 10 32.5 ( $\mathrm{mol} \%$ ) 組成のガラスで分相

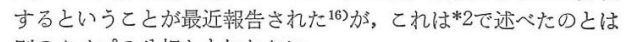
別のタイプの分相かも知れない. 
アルカリ金属酸化物のように，必らずしもイオン半 径の順にはならない. 比較的顕著な効果を示すものは 次のよらなものである.

分相を助長するもの……..... $\mathrm{P}_{2} \mathrm{O}_{5}, \mathrm{TiO}_{2}$ など . 分相を抑制するもの…............ $\mathrm{Al}_{2} \mathrm{O}_{3}, \mathrm{ZrO}_{2}, \mathrm{PbO}$, $\mathrm{MgO}$ など.

$\mathrm{B}_{2} \mathrm{O}_{3}$ は, Fig. 9 に示すように, 少量の添加では分 相を抑制するが，添加量が増加すると逆に分相を助長 するよらになる。

\section{$5 \quad \mathrm{Na}_{2} \mathrm{O}-\mathrm{B}_{2} \mathrm{O}_{3}-\mathrm{SiO}_{2}$ 系ガラスの分相}

$\mathrm{Na}_{2} \mathrm{O}-\mathrm{B}_{2} \mathrm{O}_{3}-\mathrm{SiO}_{2} 3$ 成分系では, Fig. 10 の, $B$, $C$ で示すような三つの分相領域が存在する. そのらち，

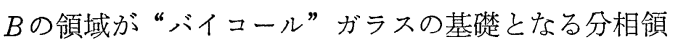
域（Fig. 9 (c)のガラスはこの組成域に属する）である. そのため, $B$ の領域に属するガラスにおける分相現象 に関しては，従来から数多くの報告が発表されて和り， 現在でもな和大型でしかもシリカ含有率の高い“バイ コール”系高珪酸ガラスを収率よくうるための研究が 続けられている.それとともに, 分相したガラスの可 溶成分を溶出除去した後の多孔性ガラスが，触媒の担 体や分子らるいあるいはろ過板として有望であると期 待されていることから, 孔の大きさや比表面積を制御 するための条件の検討がなされている。

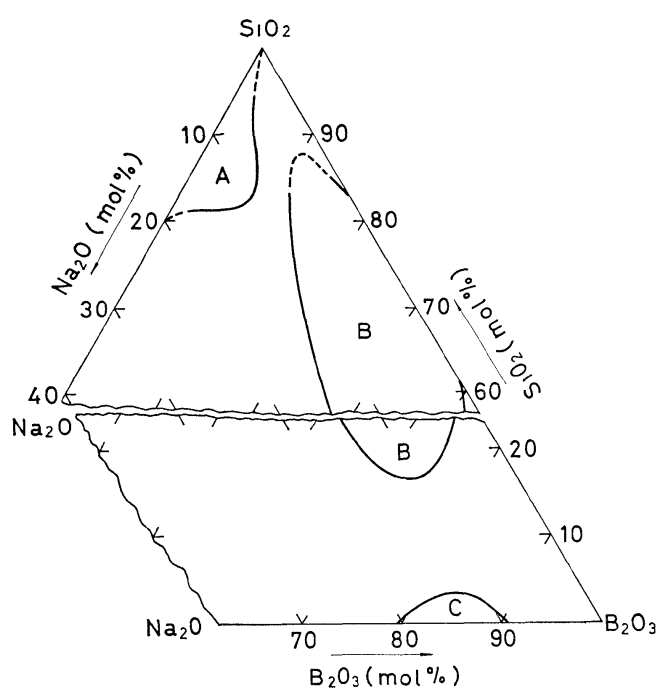

Fig. 10. Phase separable regions in $\mathrm{Na}_{2} \mathrm{O}-\mathrm{B}_{2} \mathrm{O}_{3}-\mathrm{S}_{1} \mathrm{O}_{2}$ ternary system.

\section{6 分相と結晶化の関係}

スピノーダル分解によるときはもとより，核生成一 成長機構によるときでも，通常ガラスーガラス間の界 面張力は結晶一ガラス間のそれより小さいので，分相 は結晶化に先行しやすい。この先行して生じた分相が 後の結晶化にどのような影響を与えるかは，ガラスの 結晶化過程を研究する者にとって非常に興味深い問題
である。一般的にい党ば，分相は以下の理由によって ガラスの微結晶化に有利に作用すると思われる。

（1）分離相の一つが非常に失透しやすい組成ならば， たとえ元のガラスが安定であっても結晶化しやすくな る(結晶核形成剂を含まない場合)。

(2) 主結晶の結晶核として析出すべき成分，たとえ ば $\mathrm{TiO}_{2}$ や $\mathrm{ZrO}_{2}$ が分離相の一つに濃縮され, その後 の熱処理で析出し, それを核として全体の結晶化が進 行しやすくなる（結晶核形成剤を含む場合）.

（3）分相によって生じた結晶化しやすい相が微細で あれば，析出結晶も微細となる可能性が強い。

（4）分相粒子とマトリックスとの界面が結晶核生成 を促進する。Fig. 11 のように，不純物の上に接触角 $\theta$ をもって，ガラス相から結晶が球帽状に析出する場 合，不均質核生成速度 $I_{c}^{\prime}$ は(3)式のようになる。

$$
\begin{aligned}
I_{c}^{\prime} & =\text { const }^{\prime} \cdot \exp \left[-\frac{1}{k T}\left\{\Delta G+W_{s}^{*}\right\}\right] \\
& =\text { const }^{\prime} \cdot \exp \left[-\frac{1}{k T}\left\{\Delta G+W^{*} f(\theta)\right\}\right]
\end{aligned}
$$

ただし $f(\theta)=(2+\cos \theta)(1-\cos \theta)^{2} / 4$ である.

したがって $\theta$ が小さい（析出すべき結晶が界面に濡 れやすい) 汇ど $f(\theta)$ は小さく， $I_{c}^{\prime}$ は大きくなる. すなわち結晶は析出しやすくなる。

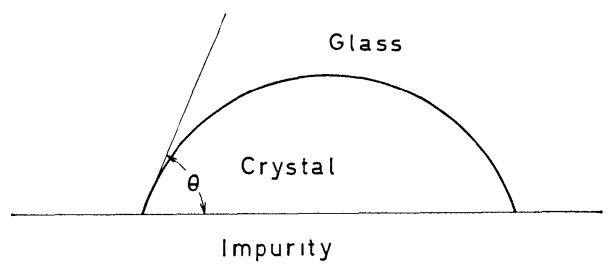

F1g. 11. Formation of crystal on the surface of impurity, where $\theta$ is contact angle between the glass and the solid surface of impurity.

さらに分相粒子とマトリックスとの間に拡散層が存 在し，その層内に核形成剤が濃縮されて界面張力を減 少させるように作用するならば，いっそら結晶核の生 成を容易にするであろう。

以上のよらに，一般論としては分相はガラスの徵結 晶化に対する有利な先駆現象と考光られる。乙かし実司 際のガラスに拈いて，分相が結晶化に対してどのよう に作用しているかを知るためには，個々の組成につい て検討してみる必要があろう。

\section{$6 \cdot 1 \quad \mathrm{Li}_{2} \mathrm{O}-\mathrm{SiO}_{2}$ 系のガラス}

Fig. 5 に拈いて，xの組成(たと光ば $\mathrm{SiO}_{2} 75, \mathrm{Li}_{2} \mathrm{O}$ $25(\mathrm{~mol} \mathrm{\%}))$ のガラスを温度 $T$ に保持すると，まず $a ， b$ の組成のガラスに 2 相分離し， $a$ の組成の方が 球状になる．分相の結果生じた $b$ 組成は，元の組成 より $\mathrm{Li}_{2} \mathrm{O} \cdot 2 \mathrm{SiO}_{2}$ 結晶の融解温度(破線で示す)から の過冷却度が大きく，粘性係数は小さい，その上組成 
も析出結晶のそれに近いので，結晶ーガラス間の界面 張力も小さく，乙たがって $\mathrm{Li}_{2} \mathrm{O} \cdot 2 \mathrm{SiO}_{2}$ 結晶はbの 組成の部分から析出しやすくなると予想される。事実 そのと挌りで每る。しかしこの系のガラスでは，分相 粒子数と析出結晶粒子数との間にとくに相関関係がみ られないので, 内部界面の存在が結晶析出に有効に作 用しているかどらか疑問である。

\section{$6 \cdot 2 \mathrm{Li}_{2} \mathrm{O}-\mathrm{MgO}-\mathrm{Al}_{2} \mathrm{O}_{3}-\mathrm{SiO}_{2}$ 系のガラス}

Ohlberg らによると， $\mathrm{SiO}_{2} 53, \mathrm{Al}_{2} \mathrm{O}_{3} 19, \mathrm{MgO} 15$, $\mathrm{Li}_{2} \mathrm{O} 13$ (wt \%) 組成のガラスでは, 熱処理によって 生じた球形の分相粒子とマトリックスとの界面が結晶 核の生成に有効に作用し，まず界面で結晶が析出し， 乞の後球形粒子の内部に向けて成長する。この機構を 示咬するのが熱処理したガラスの薄板をクロスニコル を通して観察した Fig. 12 の顕微鏡写真である。これ によると，球形粒子の市るものは界面の部分の久が， また他のものは粒子全体がマトリックスの部分より複 属析が高くなって特り, 界面が先に結晶化し, その後 内部に向けて成長するさまがわかる。

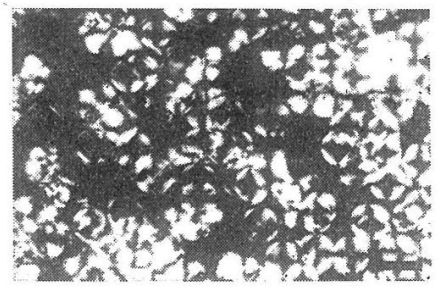

Fig. 12. Thin section of $\mathrm{SiO}_{2} 53, \mathrm{Al}_{2} \mathrm{O}_{3} 19, \mathrm{MgO} 15$, $\mathrm{Li}_{2} \mathrm{O} 13$ (wt \%) glass observed through crossed Nicol after heat treatment at $595^{\circ} \mathrm{C}$ for $96 \mathrm{hr}$ followed at $650^{\circ} \mathrm{C}$ by $30 \mathrm{~min}$. Black bar represents $0.1 \mathrm{~mm}$ (See reference 18).

\section{$6 \cdot 3 \mathrm{Li}_{2} \mathrm{O}-\mathrm{SiO}_{2}-\mathrm{TiO}_{2}$ 系のガラス}

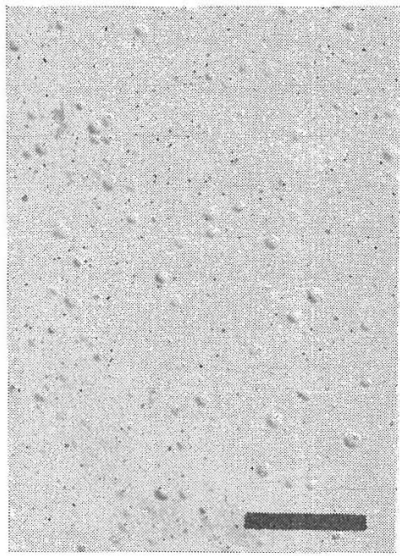

(a) 0

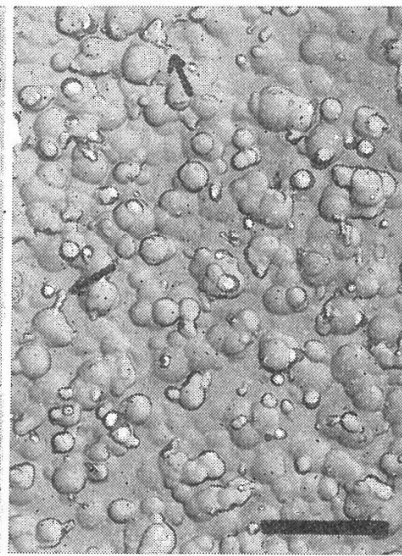

(b) 5.5
中川らは $\mathrm{SiO}_{2} 68, \mathrm{Li}_{2} \mathrm{O} .5, \mathrm{TiO}_{2} 22.5$ (wt \%) 組 成では, 分相粒子の周辺から直径約 $250 \AA$ の $\mathrm{Li}_{2} \mathrm{O}$ 。 $\mathrm{TiO}_{2}$ 結晶が析出し，その $\mathrm{Li}_{2} \mathrm{O} \cdot \mathrm{TiO}_{2}$ 結晶が主結晶 $\mathrm{Li}_{2} \mathrm{O} \cdot 2 \mathrm{SiO}_{2}$ の結晶化の核として作用すると報告して いる. そして分相によって $\mathrm{Li}_{2} \mathrm{O} \cdot \mathrm{TiO}_{2}$ 結晶が析出し やすくなる理由として，核生成のための熱力学的障壁 が分相粒子とマトリックスとの界面で減少するためか， あるいは $\mathrm{TiO}_{2}$ と $\mathrm{Li}_{2} \mathrm{O}$ の濃度が界面層で増加するた めであろうと推測している。

\section{$6 \cdot 4 \mathrm{Li}_{2} \mathrm{O}-\mathrm{SiO}_{2}-\mathrm{P}_{2} \mathrm{O}_{5}-\mathrm{Al}_{2} \mathrm{O}_{3}$ 系のガラス}

4 で述べたように， $\mathrm{P}_{2} \mathrm{O}_{5}$ は分相助長剤として作用 する。したがって，そのままの組成では分相しない $\mathrm{SiO}_{2} 80, \mathrm{Li}_{2} \mathrm{O} 20$ (wt \%) $\left(\mathrm{Li}_{2} \mathrm{O} \cdot 2 \mathrm{SiO}_{2}\right.$ に相当する) に4（wt \%) の $\mathrm{P}_{2} \mathrm{O}_{5}$ を添加した組成では，熱処理 によって分相して無数の球形粒子（希フッ化水素酸に 難溶）劣分離する。熱処理時間が増加すると，6・1の 場合と同様に， $\mathrm{P}_{2} \mathrm{O}_{5}$ を含むマトリックスの部分から $\mathrm{Li}_{2} \mathrm{O} \cdot 2 \mathrm{SiO}_{2}$ 結晶が析出与る。

ところが上記の組成に $\mathrm{Al}_{2} \mathrm{O}_{3}$ を少量加えた組成で は, 熱処理しても分相が起こらなくなる。しかし $\mathrm{Al}_{2}$ $\mathrm{O}_{3}$ の添加量をさらに増加すると, 今度は, 熱処理に よって, 希フッ化水素酸に易溶な球形粒子分離相と する第2のタイプの分相が起こるよらになる。この第 2 のタイプの分相が先行する組成のガラスでは, 加熱 時間を增加すると，Fig. 13 に示すように，分相粒子 の表面付近あるいは内部から突き出たような形で希フ ッ化水素酸にさらに溶けやすい部分（矢印で示す）が 生じ，圥机を元にして主結晶 $\mathrm{Li}_{2} \mathrm{O} \cdot 2 \mathrm{SiO}_{2}$ が析出す るよらになる。このようにして分相粒子が後の結晶化 に関与するため，分相粒子数が多いほど細かい結晶の 集合体になりやすい。

Fig. 13. Electron micrographs of fracture surfaces of $\mathrm{SiO}_{2} 80, \mathrm{Li}_{2} \mathrm{O} 20+\mathrm{P}_{2} \mathrm{O}_{5} 4+\mathrm{Al}_{2} \mathrm{O}_{3} 7.2$ (wt \%) glasses heat treated at $530^{\circ} \mathrm{C}$ for various times. Numbers represent relative crystallinity. Black bars represent 2 micron.

$\begin{array}{lll}\text { (a) } 1 \mathrm{hr} & \text { (b) } 2.5 \mathrm{hr} & \text { (c) } 4 \mathrm{hr}\end{array}$

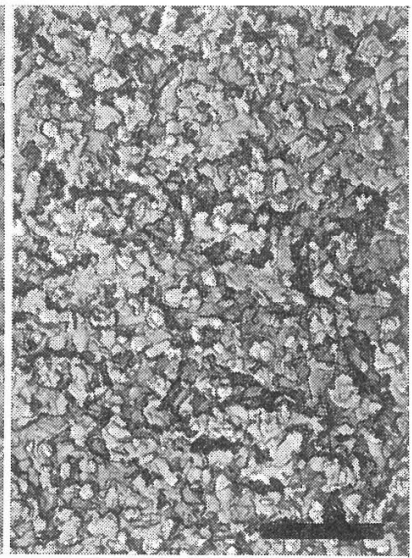

(c) 46 


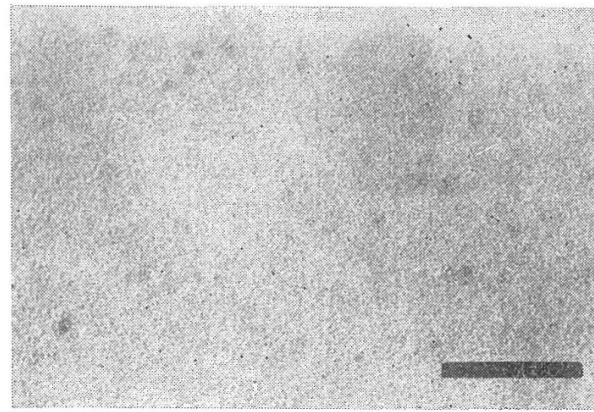

(a) No. 1

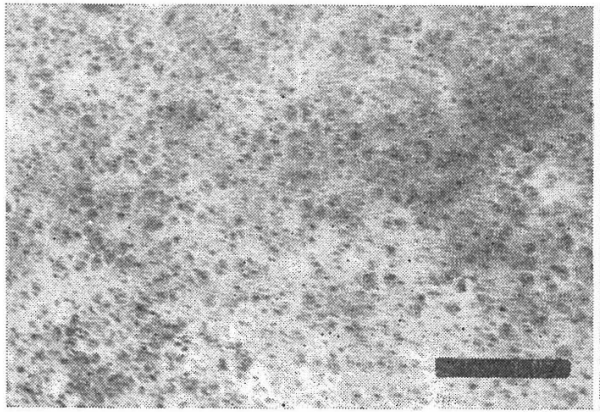

(c) No. 8

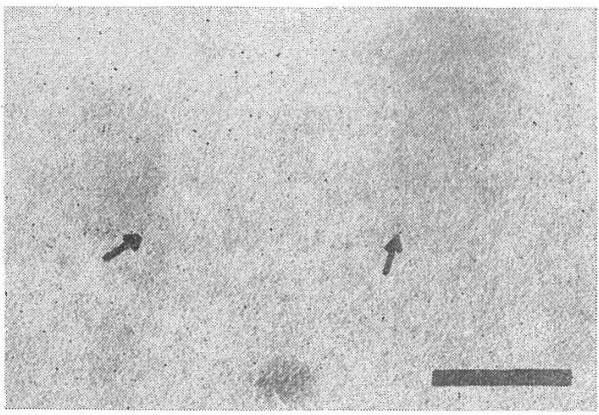

(b) No. 2

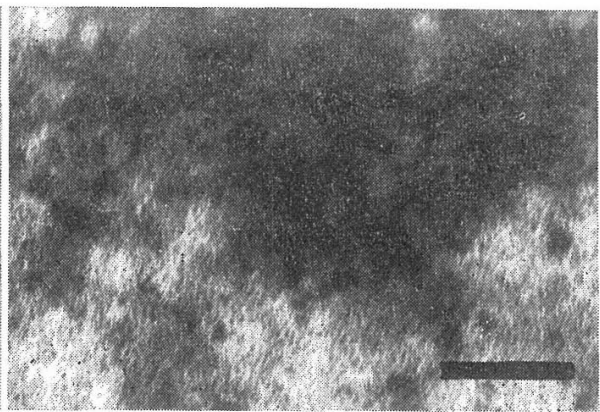

(d) No. 11

Fig. 14. Direct transmission electron micrographs of thin films of glasses given in Table I. Black bars represent 0.2 micron.

\section{7 実際の結晶化ガラスの場合}

上述の結果は実用の結晶化ガラスの結晶化過程を知 る上できわめて示唆に富むるのである。しかし用いた ガラスの組成や析出結晶の大きさなどが実用の結晶化 ガラスのそれに比べていくぶて異なっているので, 実 用の組成のガラスで起こる現象は上述の結果と必らず しも同じとは限らない, そこで, 以下に市服品に近い 組成の透明結晶化ガラスの生成過程中で起こる構造変 化についての観察結果を簡単に述べる。

対象としたガラスは，その基本成分が $\mathrm{SiO}_{2}, \mathrm{Al}_{2} \mathrm{O}_{3}$

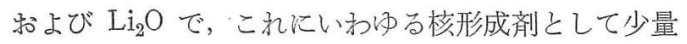
の $\mathrm{P}_{2} \mathrm{O}_{5}+\mathrm{TiO}_{2}+\mathrm{ZrO}_{2}$ 党含豆もので, 室温より $5^{\circ} \mathrm{C} /$ min で $750^{\circ} \mathrm{C}$ まで加熱し, そこで 1 時間保持（核生成 処理), さらに $5^{\circ} \mathrm{C} / \mathrm{min} て ゙ 80^{\circ} \mathrm{C}$ ま加熱, そこで再 び1時間保持（結晶化処理）した後放泠することによ り耐熱衝整性の大きい透明結晶化ガラスに変わりうる るので岁る。

Fig. 14 は Table I に示す条件で熱処理したガラス の薄膜の直接透過法による電子顕微鏡写真である。

Fig. 14 をみると, 熱処理前のガラス (No.1) では,

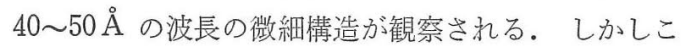
の状態では電子回折でもX線回折でもなんら特別な回 折線が認められないので, 微細構造は分相に起因して いるるの之思われる。核生成処理したガラス（No. 2) では，全体的な組成変動はさらに顕著になって抢り，
Table I. Heat treatment conditions for glass samples.

\begin{tabular}{c|cccl}
\hline Sample No. & \multicolumn{4}{l}{ Heating rate Holding Heating rate Holding } \\
1 & No heat treatment (Original glass) & \\
2 & $5{ }^{\circ} \mathrm{C} / \mathrm{min}$ & $1 \mathrm{hr}$ at $750^{\circ} \mathrm{C}$ & \\
8 & " & " & $5^{\circ} \mathrm{C} / \mathrm{min}$ & $1 \mathrm{hr}$ at $775^{\circ} \mathrm{C}$ \\
11 & " & " & " & $1 \mathrm{hr}$ at $850^{\circ} \mathrm{C}$
\end{tabular}

ガラスの分相が促進されている. そのほか，このガラ スでは矢印で示したような直径約 $30 \AA$ の細かい粒子 が認められる。この粒子は $\mathrm{CuK} \alpha 2 \theta=30.6^{\circ}$ 付近に 回折線老持つ結晶 (多分 $\mathrm{ZrO}_{2}$ 西るいは $\mathrm{ZrTiO}_{4}$ ) の 初期のものである. 結晶化直前のガラス (No. 8) では, さらに多数の粒子 (直径約 $60 \AA$ の結晶) が観察され

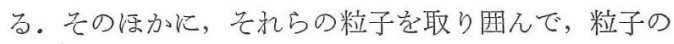
直径の約 3 倍のコントラストの異なる領域が明りよら に認められる。この状態でも, たんに $2 \theta=30.6^{\circ}$ 付近 の回折線が認められるでけなので, 結晶粒子を取り囲 んでいる領域はいまだ非晶質である。結晶化の進んだ ガラス (No.11) では, ここに示した直接透過像では それほど明りようではないが，暗視野像や電子回折の 結果から，上記の結晶のほかに多量の主結晶（ $\beta$ 一石 英の固溶体)の析出が認められている。

このような一連の電子顕微鏡観察に加えて, X線回 折ピークの広がりを基にした結晶の大きさ和よび非晶 
質のX線散乱強度を利用した結晶化度の測定值から， 著者は次のような結晶化の機構を提案した。すなわら, 融液から泠却されたガラスにはすでに $40 \AA$ 程度の波 長の分相が起こっており, $\mathrm{Zr}^{4+}$ や $\mathrm{Ti}^{4+}$ は一方の相 に濃縮されている可能性が強い. $750^{\circ} \mathrm{C}$ までの加熱と その温度に保持することにより, 分相が助長されると 同時に $\mathrm{Zr}^{4+}$ (あるいは $\mathrm{Zr}^{4+}$ と $\mathrm{Ti}^{4+}$ ) は集合し，約 $40 \mathrm{~min}$ の潜伏期間の後 $25 \sim 30 \AA$ の結晶 $\left(\mathrm{ZrO}_{2}\right.$ ある いは $\left.\mathrm{ZrTiO}_{4}\right)$ に変化する。ささら温度を上げると， 上記の結晶（これが主結晶の核になる）の数が増加す るとともに約 $60 \AA$ まで成長する。それとともに，そ の核のまわりに主結晶に近い組成の非晶質の領域が形 成される。 その領域は $800^{\circ} \mathrm{C}$ 付近から主結晶に変化乙 始め, $850^{\circ} \mathrm{C}$ までの加熱执よびその温度での保持によ り約 $300 \AA$ に成長し, 以後は結晶が互いに接触し合う まで充分結晶化が進行する。

このような結晶化の機構は, アメリカのコーニング 社コード番号 9608 結晶化ガラスに対して, Doherty らによって推定されな機構と基本的にはかなりよく似 て拉り，低膨張の実用の結晶化ガラスにおける結晶化 の機構として充分可能性のあるものと考えられる.

\section{8 あとがき}

以上, ガラスの分相および分相が先行する場合のガ ラスの結晶化過程について概略を説明した．分相現象 そのものについていえば，“バイコール”ガラスの発 明が刺激となって分相に関する研究が数多く行なわれ るようになったといら経緯を考慮すれば， $\mathrm{Na}_{2} \mathrm{O}-\mathrm{B}_{2} \mathrm{O}_{3}$ 系および $\mathrm{Na}_{2} \mathrm{O}-\mathrm{B}_{2} \mathrm{O}_{3}-\mathrm{SiO}_{2}$ 系ガラスの分相についてく わしく述べるべさだったか子知れない。しかし現在で は，なぜ，どのような機構でガラスは分相するのか， あるいは分相が後の結晶化に対してどのような影響を 与えるかといら点に多くの関心が寄せられていると思 われるので，上記の系を初め，他の系の例についても 省略させていただいた．またスピノーダル分解機構に ついても，紙数の関係で多くを述べることができなか った．これについては文献 2）と9）を中心とする原 論文を参照されたい。このほか，最近開発された光を 照射すると透過率が減じ, 光を遮断すると回復する, いわゆる透過率可変ガラスの製造に際して, ハロゲン 化銀の析出に分相が関与するかどうかか議論のあるとこ ろであるが，これについては別の機会に報告したい。 全体を通じて, 著者の独断や誤りが少なくないと思わ れるが，各位のご叱正が得られるならば幸いである。

\section{考文 献}

1）成瀬 省, “ガラス工学”, p 37 (1958), 共立出版

2) Cahn, J.W., and R. J. Charles, Phys. Chem. Glasses, 6, 181 (1961).

3) Levin, E M, H.F. McMurdie, and F.P. Hall Ed, “Phase Diagrams for Ceramists”, p. 48, Fig. 49 (1956), Am. Ceram. Soc. Inc.,

4) Toropov, N.A., S. Ya. Golakhov, and I. A. Bondar, Bull. Acad. USSR, Div. Chem. Sci., (6), 641 (1956).

5）横田良助, 案協, 74, 101 (1966).

6) Ohlberg, S. M., and J.J. Hammel, VII International Congress on Glass (1965), Brussels, Paper 32

7) Ohlberg, S. M., J. J. Hammel, and H. R. Golob, J. Am. Ceram. Soc., 48, 178 (1965), See also 5.

8) Moriya, Y., D H. Warrington, and R.W. Douglas, Phys. Chem. Glasses, 8, 19 (1967).

9) Cahn, J. W., J. Chem. Phys., 42, 93 (1965).

10) Haller, W., J. Chem. Phys., 42, 686 (1965).

11）守屋喜郎, “第 1 回ガラス部会討論会講演 要旨集”, p. 101 (1967), 窯業協会ガラス部会

12) McCurrie, R.A., and R.W. Douglas, Phys. Chem. Glasses, 8, 132 (1967); Zarzycki, J., and F. Naudin, ıbıd., 8, 11 (1967).

13) Kingery, D. W., and J. A. Lecron, Phys. Chem. Glasses, 1, 11 (1960).

14）守屋喜郎, 大工試季報, 21, 1 (1970).

15）守屋喜郎, 窯協, 78, 196 (1970).

16) Cupta, Y. P., and U. D. Mishra, J. Phys. Chem. Solids, 30, 1327 (1969).

17）たとえば Volf, M. B., “Technical Glasses”, Chapter 10 (1961), Pitman, London; 森谷太郎, 成瀬 省, 功 刀雅長, 田代仁編, “ガラス工学ハンドブック”, p. 275, p. 651 (1963), 朝倉書店

18) Reser, M.K., G. Smith, and H. Insley Ed., "Symposium on Nucleation and Crystallization in Glasses and melts", p. 55 (1962), Am. Ceram. Soc. Inc.,

19) Nakagawa, K., and T. Izumitani, Phys. Chem. Glasses, 10, 179 (1969).

20）守屋喜郎, 京都, 大阪, 中国四国支部共催案業協会学術 講演会 (1969).

21）守屋喜郎, 愙協, 76, 293 (1968).

22) Doherty, P.E., D.W. Lee, and R.S. Davis, J. Am. Ceram. Soc., 50, 77 (1967).

23）鈴木由郎, 特公, (1968)-16522.

24) Mitchel, J. W., R.C. Devries, R. W. Roberts, and P. Cannon, Ed., "Proceedings of the 6th International Symposium on the Reactıvity of Solıds", p. 695(1969), Wily-Interscience 